\title{
Interactive comment on "Biogeochemical
} constraints on the origin of methane in an alluvial aquifer: evidence for the upward migration of methane from a coal seam" by Charlotte P. Iverach et al.

\section{Anonymous Referee \#2}

Received and published: 17 October 2016

The comment was uploaded in the form of a supplement:

http://www.biogeosciences-discuss.net/bg-2016-359/bg-2016-359-RC2-

supplement.pdf 